This is an Accepted Manuscript of the article Siciliano, G., Del Bene, D., Scheidel, A., Liu, J., \& Urban, F. (2019). Environmental justice and Chinese dam-building in the global South. Current Opinion in Environmental Sustainability, 37, 20-27, available online at

https://doi.org/10.1016/i.cosust.2019.04.003 @2019. This manuscript version is made available under the CC-BY-NC-ND 4.0 license

\title{
Environmental Justice and Chinese dam-building in the global South
}

\author{
Giuseppina Siciliano ${ }^{a}$, Daniela Del Bene ${ }^{b}$, Arnim Scheidel $^{b}$, Juan Liu ${ }^{b}$, Frauke Urban $^{c}$ \\ ${ }^{a}$ Centre for Development Environment and Policy, SOAS, University of London, UK \\ ${ }^{b}$ Institut de Ciència i Tecnologia Ambientals (ICTA), Universitat Autònoma de Barcelona (UAB) \\ c KTH Royal Institute of Technology, Stockholm, Sweden
}

Corresponding author: Giuseppina Siciliano, Centre for Development Environment and Policy, SOAS, University of London, 36 Gordon Square, London, WC1H OPD, UK, E-mail address: g.siciliano@soas.ac.uk.

\section{Keywords}

Hydropower; Chinese investments; Environmental Justice;

\section{Introduction}

After a period of relative stagnation, in recent years the construction of hydropower dams has experienced an unprecedented global boom in both scale and extent [1]. The global hydropower installed capacity has grown by $39 \%$ in the period $2005-2015$, with an average growth rate of about $4 \%$ per year (World Energy Council Database, URL: https://www.worldenergy.org/data/resources/resource/hydropower/). Zarfl et al. [1] estimate that $40 \%$ of the total future electricity capacity addiction from hydropower will be installed in low and middle income countries.

Until the early 2000s, the World Bank was the largest financier of large-scale hydropower development in low and middle income countries. However, due to the massive social and environmental impacts associated with large dam constructions [2] and the increasing public contestations $\left[3^{* *}\right]$, the sector went into a lull during the 1990 s and many projects were dropped. After 2000, Chinese companies and banks became global leaders in large hydropower dam development, especially thanks to a series of Chinese internationalization policies, of which the most relevant are the 2000 "Going-Out" strategy and the 2013 "Belt and Road Initiative" [4]. The driving forces behind this were equally economic and political [5].

These strategies encouraged Chinese State-Owned Banks (SOBs) and Enterprises (SOEs), as well as private enterprises, to engage in new investments in infrastructure development abroad with the authorization and financial support of the central government [6**]. According to the most updated database available on Chinese overseas engagement in hydropower (last updated in September 2017), 96\% of Chinese overseas hydropower projects have been built and planned after 2000 [4]. Some of these large dam projects have been questioned in the literature mainly regarding socialecological changes, transboundary and governance issues, and in relation to environmental justice and ecological distributional aspects $\left[7,8,9,10^{*}, 11^{*}, 12^{*}, 13^{* *}, 14,15^{* *}, 16^{* *}\right]$.

In this paper we set out to explore the drivers and conflictive outcomes linked to the socialenvironmental governance and management challenges of Chinese large dam constructions in the 
global South. We reflect on the body of literature published in recent years on Chinese dam developers' engagement overseas and on Chinese dam projects located in different regions of the world by using information from the Global Atlas of Environmental Justice (EJAtlas Database, URL: https://ejatlas.org/).

\section{"Push" and "pull" factors of Chinese overseas dam-building in the global South}

With an estimated 380 large dam projects in more than 70 countries worldwide either built, under construction or planned, Chinese companies and banks are today the biggest hydropower builders and financiers at the global level [4]. Most of the Chinese overseas large dams have been built or planned in the period 2006-2017, and they are located in developing countries in South and Southeast Asia, Africa and Latin America (Table 1). With about $40 \%$ of the whole projects, Southeast Asia represents the preferential geographical localization of Chinese hydropower development for obvious reasons of geographic proximity, physiographic conditions of rivers, close political and economic relationships and cultural similarities [4].

Table 1 Estimated hydropower capacity and percentage of Chinese overseas hydropower projects (built, planned and under construction) by region, 2006-2017 [4]

\begin{tabular}{|c|c|c|}
\hline Region & $\begin{array}{c}\text { Estimation of total hydropower } \\
\text { capacity (MW) }\end{array}$ & $\begin{array}{c}\text { Estimated number of } \\
\text { hydropower projects (\%) }\end{array}$ \\
\hline Asia (SE) & 63444 & 41 \\
\hline Asia (S) & 26822 & 10 \\
\hline Africa & 21210 & 25 \\
\hline Latin America & 9631 & 10 \\
\hline Europe & 5984 & 10 \\
\hline Asia (Central) & 2151 & 3 \\
\hline Middle East & 558 & 1 \\
\hline Oceania & 180 & 0 \\
\hline Pacific & 59 & 1 \\
\hline
\end{tabular}

As China has become the leading actor in dam-building in the global South, there have been increasing interests from academia and international organizations to look the motives of Chinese State Owned Banks (SOBs) and Enterprises (SOEs). Based on the literature on Chinese overseas engagement in hydropower development, in Table 2 we distinguish between "push" and "pull" factors of Chinese overseas dam-building, differentiating between diversified drivers and motives that "push" Chinese banks and hydropower companies to invest abroad and "pull" factors as the motives of the host governments to welcome Chinese hydropower investments.

Table 2 Push and pull factors of Chinese overseas investments in hydropower

\begin{tabular}{|c|c|c|}
\hline Drivers & Push factors (Chinese investors and financiers) & Pull Factors (host countries) \\
\hline Political & $\begin{array}{ll}- & \text { Going Out Strategy (1.0 and 2.0) } \\
\text { - } & \text { Belt and Road Initiative }\end{array}$ & $\begin{array}{l}\text { - Improve energy access and energy security } \\
\text { - Development and economic growth } \\
\text { - } \quad \text { "No strings attached" }\end{array}$ \\
\hline Economic & $\begin{array}{l}\text { - } \text { Access to new hydropower markets for } \\
\text { hydropower companies } \\
\text { - } \quad \text { Access to cheap loans for hydropower } \\
\text { companies } \\
\text { - } \quad \text { Bundling of aid, trade and investments }\end{array}$ & $\begin{array}{ll} & \text { Access to finance } \\
\text { - } & \text { Low costs and reduction of overrun costs } \\
\text { - } & \text { Bundling of aid-trade and investments } \\
\text { - } & \text { Industrial development }\end{array}$ \\
\hline Geopolitical & $\begin{array}{l}\text { - Access to natural resources (water, } \\
\text { minerals, fossil fuels) } \\
\text { - Geographical proximity, political } \\
\text { relationships and cultural similarities }\end{array}$ & $\begin{array}{ll}\text { - } & \text { Climate change mitigation } \\
\text { - } & \text { Investment in low carbon energy } \\
\text { - } & \text { Establish new international } \\
& \text { alliances (esp. for Latin America) }\end{array}$ \\
\hline
\end{tabular}




\begin{tabular}{|l|l|l|l|}
\hline & $\bullet$ & Hydropower imports & \\
\hline Reputational & $\bullet \quad \begin{array}{l}\text { Help countries from the Global South to } \\
\text { develop }\end{array}$ & $\begin{array}{l}\text { Icons of modernity } \\
\text { Desire to become the biggest dam- } \\
\text { building player at the global level }\end{array}$ & $\begin{array}{l}\text { International agreements on Climate Change - } \\
\text { Clean Development Mechanism (CDM) projects }\end{array}$ \\
\hline
\end{tabular}

Emerging in 1999 the Going Out Strategy of China coincided with China's 2001 admission to the World Trade Organization (WTO) and urged Chinese firms to take advantage of the world trade by investing in global markets. Also the "Belt and Road Initiative" established in 2013 aimed to expand Chinese trade and investments including investments in hydropower along the land-based "SilkRoad Economic Belt" (SREB) and the sea-based "Maritime Silk Road" (MRS). This initiative takes advantage of international transport routes as well as core cities and key ports to build six international economic co-operation corridors and further strengthens bilateral and multilateral economic agreements between China and other nations. lit supports Chinese investments in hydropower across Central Asia and along the maritime route from the South China Sea to the Indian Ocean, East Africa, the Red Sea and the Mediterranean [17, 18*].

These strategies have different aims: economic, reputational and geopolitical. From a reputational point of view they have the ambition to set China as a global leader in international cooperation by helping low and middle income countries to develop through the provision of infrastructures mainly in mobility (i.e. road, railway, port construction), energy, and agricultural sectors [17, 5, 19]. From an economic point of view they have the intention to push Chinese firms to seek for new market opportunities abroad, especially for oversaturated national markets with high domestic expertise and stiff competition, such as the hydropower sector $\left[20,15^{* *}\right]$. The expansion of Chinese hydropower firms aboard is highly supported by the lack of many international competitors and copious state funding, particularly through preferential loans from Chinese state-owned banks, and well-funded financial institutions such as Exim Bank of China [6**] and more recently the Silk Road Fund and potentially from the new multilateral development bank, the Asian Infrastructure Investment Bank (AIIB). Many of the Chinese hydropower companies are SOEs and often business decisions are influenced, initiated and guaranteed by the Chinese Government regardless of whether they bring positive returns $\left[15^{* *}\right]$. At the same time, the peculiarity of Chinese overseas dam-building is the bundling of aid, trade and investments [20]. For example, Chinese overseas investments in hydropower can be a package rather than a separate initiative, which comprises not only investments in the construction of the dam but also in different infrastructures and economic sectors, concessional loans, as well as trade agreements all together $\left[20,18^{*}\right]$. The bundling of aid, trade and investments of Chinese hydropower is sometimes linked to geopolitical drivers, particularly the seeking for new trade agreements to access natural resources, such as energy, food, water and minerals [18*, 22, 23, 24, 25] (EJAtlas Database, URL: https://ejatlas.org/conflict/hatgyidam-myanmar; EJAtlas Database, URL: https://ejatlas.org/conflict/myitsone-dam-on-irrawaddyriver-myanmar). Another peculiarity of Chinese investments overseas is the "no-string attached" policy, which means that they tend to pursue a non-interference policy with little, if any, political preconditions for the host countries [26; 15]. This attitude to business relations differs from the conditions imposed by Western countries, or other international aid organizations, such as the World Bank or International Monetary Fund, which prescribe a number of conditions to be met, including specific environmental and political conditions (e.g. human rights, democracy, and international labor standards) [27]. 
Comparatively low costs, reduction of overrun costs, technical capacity, access to large finance with low or no-conditionality attached and on occasion cheap loans in a time when other OECD investors decided to opt out of large hydropower dam construction, make Chinese investors attractive partners for low and middle income countries that are struggling with electricity access and energy security and most importantly that have low capital and technical capacity to invest in big infrastructure projects (Table 2) [15**, 21*, 28]. Hydropower dams also represent an opportunity for developed countries to invest in climate change mitigation strategies in low and middle income countries through the United Nations' carbon-offsetting scheme Clean Development Mechanism (CDM), and more recently also through the Green Climate Fund [29]. Despite the high number of large hydro projects in the CDM pipeline, climate neutrality of large hydropower dams and reservoirs is questioned by some scholars [30,31]. Some scholars and activists argue that it should not be included in climate mitigation programs such as the CDM [32,33]. Key contentious issues are methane emissions caused by submerged organic matter in stagnant water of reservoirs, particularly in the tropics $[34,35]$. Yet, some countries depend almost entirely on hydropower for their electricity generation such as Nepal and Mozambique, and any large-scale alternatives would most likely be fossil fuel-based. From a reputational point of view, large dams are also considered "powerful icons of modernity, economic success, national prestige and technological progress" [36], especially in low and middle income countries.

\section{Environmental justice and conflictive aspects of Chinese overseas dam projects}

Studies on environmental justice in large hydropower dam development is today a growing research field $\left[28,37,38,39,40,41,3^{* *}, 50,64\right]$. Moreover, growing investment into large hydropower dams in the global South has been associated with the rise of ecological distribution conflicts and violence [3**]. Such conflicts arise over environmental injustices caused by the way how environmental benefits and burdens from large dams are distributed across different social groups, as well as over procedural issues, i.e., how institutions and power relations shape the decision-making process [42, $\left.43,16^{* *}\right]$.

Environmental justice can broadly be divided into distributive justice and procedural justice $\left[65,66^{*}\right.$, 67]. Distributive justice relates to the fair distribution of basic needs such as adequate access to food and water, housing, income and employment, basic services like healthcare as well as an equitable distribution of environmental 'bads' and 'goods'. Procedural justice relates to fair, accountable and transparent decision-making in relation to the environment $\left[66^{*}, 67\right]$. Schlosberg argues that in addition, issues of recognition, capabilities and participation need to be addressed to achieve environmental justice [66*]. In recent years, the concept of energy justice has gained more prominence, which refers to the fair and equitable distribution of the costs and benefits of energy services (hence distributive energy justice), as well as fair, accountable and transparent energy decision-making (hence procedural energy justice) $[68,69]$. In this line of reasoning, Moran et al (2018) argue that the hydropower industry needs to focus more on addressing the adverse social and environmental impacts of large dams and they suggest that more sustainable practices need to be adopted [72].

Overseas Chinese investments attracted special attention in the literature for the novelty of its actors and dynamics, as well as its size, speed of investment and global coverage [15**]. In Table 3 we provide an analysis of the main controversial aspects of hydropower investments that have resulted or may result in environmental justice concerns and conflicts between dam-builders, host governments, and local communities. 
Table 3 Conflictive dimensions and aspects of hydropower investments in the global-South

\begin{tabular}{|c|c|}
\hline Dimension & Key conflictive aspects \\
\hline Geography and responsibility & $\begin{array}{ll} & \text { Siting (environmental and social risks) } \\
\text { - } & \text { Rural-urban relations } \\
\text { - } & \text { Transboundary issues } \\
\text { - Impacts on vulnerable groups (e.g. Indigenous Peoples) }\end{array}$ \\
\hline Resource access & $\begin{array}{ll}\text { - } & \text { Enclosures } \\
\text { - } & \text { Distribution } \\
\text { - } & \text { Appropriation } \\
\end{array}$ \\
\hline Governance and power relations & $\begin{array}{ll}\text { - } & \text { Accountability } \\
\text { - } & \text { Transparency and procedural justice } \\
\text { - } & \text { Inclusiveness } \\
\text { - } & \text { Social-Environmental Impact Assessment (ESIA) } \\
\text { - } & \text { Social safeguards measures } \\
\text { - } & \text { Monitoring and mitigation of the impacts } \\
\text { - } & \text { Unbalanced power relations } \\
\text { - } & \text { Unclear responsibilities } \\
\end{array}$ \\
\hline Technology transfer & $\begin{array}{ll}\text { - } & \text { Transfer of expertise, skills and knowledge } \\
\text { - } & \text { Employment }\end{array}$ \\
\hline Culture and identity & $\begin{array}{ll}\text { - } & \text { Livelihoods } \\
\text { - } & \text { Social cohesion } \\
\text { - } & \text { Recognition of different worldviews } \\
\text { - } & \text { Historical tensions }\end{array}$ \\
\hline
\end{tabular}

\section{Geography, responsibility and resource access}

The spatial dimension of energy provision, both in terms of localization of extraction and energy distribution, poses environmental justice concerns [45]. Decisions over the localization of large dams should assure the minimization of the socio-environmental impacts (procedural justice principle) and the equal distribution of benefits between populations in different geographical areas (distributional justice principle) [43], for instance, between urban and rural dwellers [44**].

The siting of large hydropower dam projects in ecologically and socially sensitive zones, such as protected areas and biodiversity hotspots, or land under Indigenous customary rights, is a central conflictive aspect identified in the literature of large dams investments in the global South. For instance, the Bakun dam in Malaysia, built in a biodiversity hotspot in Borneo following the resettlement of ca. 10,000 indigenous, has been a source of ongoing disagreements between the State, Indigenous Peoples and NGOs [46, 47*, 48*] (EJAtlas Database, URL: https://ejatlas.org/conflict/malaysia ). Yet it also needs to be acknowledged that the role of Chinese firms and financiers was limited due to extensive Malaysian development in the Bakun dam building process. Also, the hydropower developments of some OECD dam-builders are reported to have resulted in equally questionable procedures, practices and impacts, such as Salini Impregilo's Gibe III dam in Ethiopia [70, 71].

Concerning the fair distribution of benefits, the reduction of energy poverty, especially in rural areas, is one of the main justifications of large dam construction in low and middle income countries. In some countries large hydropower projects in the global South make vital contributions to energy access for rural communities $\left[49^{*}, 50^{*}\right]$. On the flip side, there are several cases where the electricity produced is not used to close the rural electricity gap, but instead electricity is exported, or used for urban development, industrial and mining productions $\left[51^{*}, 46\right]$. This aspect provokes 
distributional justice concerns, as for example for the Chinese planned Naung Pha dam in Myanmar, in which $90 \%$ of the produced electricity is planned to be exported to China, despite the government's claim to address Myanmar's growing energy needs. Social mobilizations against the dam plans have therefore arisen (EJAtlas Database, URL: https://ejatlas.org/conflict/naung-phadam-on-the-salween-river-shan-state-myanmarEjatlas).

Large hydropower dams in the global South may furthermore raise transboundary concerns and conflicts for the use of water resources between neighboring countries, as has been observed in the Mekong Basin [18*, 52]. In Vietnam for instance China's dam building activity upstream of the Mekong is perceived as potentially undermining national development due to water access security reasons, leading to political tensions between the two countries [11*]. Reduced access to land for agriculture and poor fertility of land has also been one of the main concerns of resettled communities from several foreign-built hydropower projects located in Africa and Asia, as indicated in the cases analyses in Siciliano et al., 2018b. Resource access by Chinese investors through multipurpose investments linked to large dam projects have also been analyzed in the literature and reported in the media, such as trade agreements for mining resources access in the Amazon associated to the São Luiz de Tapajós hydropower plant [23], cocoa production in Ghana associated to Bui dam [22] and access to oil resources in Ecuador associated to Coca-Codo Sinclair dam [24].

\section{Governance and power relations}

Accountability, transparency, participation and informed consent of those affected by energy projects is at the basis of justice principles in energy decision-making [43]. Moreover, restoration of the negative socio-environmental impacts is considered fundamental to ensure energy justice [53]. For dam construction this is pursued for instance with the implementation of Social-Environmental Impact Assessments (ESIA), resettlement planning frameworks, social safeguards measures, postacceptance monitoring and mitigation of the impacts, as well as inclusiveness of the entire decisionmaking process [2].

For large dams in the global South, responsibility for the implementation of such safeguards mechanisms is regulated by the host countries legislations. This is particularly the case with Chinese investments [8] for which environmental and political preconditions are rarely attached, as discussed previously. Nevertheless, the literature discusses varying degrees of responsibility of Chinese builders and financiers depending on the types of contract, i.e. Build, Operate and Transfer (BOT) and Engineering, Procurement and Construction (EPC) contracts. Under EPC contracts (turnkey contracts), the builders are responsible for the construction of the dam while the host countries take the responsibility of carrying out the preliminary studies including the EIA, provide the technical, legal and other guarantees, handling resettlement and compensation processes, monitor implementation, and operate the dams. Under BOT arrangements, the dam-building company provides technical capacity for construction and operation and maintenance in exchange of operating rights for a period of typically $20-40$ years [54*]. The company then later hands back the ownership of the dam to the host government.

According to a study by International Rivers on the implementation practices, and environmental and social commitments of seven major Chinese overseas hydropower companies, EPC Contractors outperform BOT Contractors in both policy and project assessments. Among the mentioned reasons is that EPC contracts require less long-term involvement than BOT contracts in terms of environmental and social safeguards. This highlights the challenges for the implementation of 
international, Chinese and national host country laws and standards when enforcement of regulations in the host countries is weak $\left[54^{*}, 13^{* *}\right]$.

An example is the case of the Kamchay dam in Cambodia, where law enforcement is weak $\left[6^{* *}, 8\right]$. The construction of the dam commenced in 2007, however the EIA was not completed until 2012. Justice concerns were voiced over the poor participation of affected communities, irregularities in the compensation schemes, and lacking implementation of environmental safeguards and mitigation measures $\left[51^{*}, 55^{*}\right]$. In other cases under EPC contracts, such as the Bui dam in Ghana and Bakun dam in Malaysia, international standards for the preparation of the EIA were accomplished, but opposition and complaints from resettled communities arose over poor participation, location, size and quality of the resettlement area, land scarcity, lack of proofs of house ownership, lack of employment alternatives, or lack of security services to prevent increasing crimes in the resettlement areas $[12 *, 48 *]$.

\section{Technology transfer}

Urban et al. [56*] found that in the case of BOT contracts, which requires longer-term involvement of Chinese dam-builders in the host countries, despite the transfer of technology (hardware), the transfer of skills and know-how for operation and maintenance and the knowledge and expertise for innovation in hydropower may often be limited, particularly for dam construction based on BOT contracts in countries with limited experience in the hydropower sector. This aspect can raise concerns from local workers as contracts tend to be often for short-term and low-skilled employments, such as in the case of Kamchay dam in Cambodia. More technical training of staff, job placements and joint ventures could help to build up the technical capacity of the recipient country.

\section{Culture and Identity}

The recognition of different values and worldviews in society is fundamental to achieve social cohesion and to assure that energy decisions respond to principles of procedural justice [43]. Del Bene et al $\left[3^{* *}\right]$ argue that protests against dams are frequently attempts of affected groups to protect their own ways of life and cultural understandings of sustainable resource uses. According to Hensengerth $\left[57^{* *}\right]$ the potential lacking engagement of Chinese companies with local communities and the poor recognition of their different values is likely to further exacerbate conflicts, while causing identity fragmentations and cultural losses.

A recent study on large hydropower dam in the Greater Mekong Region, for example, has shown that dam programs commonly tend to ignore different cultures and identities of affected populations, leading to value fragmentation and regional conflicts and tensions [57**]. For instance, the Lower Sesan 2 dam in Cambodia has provoked conflicts because the rights and tradition of Indigenous communities were largely ignored, including their spiritual attachments to the river [57**]. Also, the Upper Yeywa dam in Myanmar, currently under construction by Chinese companies, has become very controversial because it would flood important cultural sites and hundred years old stupas (EJAtlas Database, URL: https://ejatlas.org/conflict/upper-yeywa-dam-on-the-namtu-rivershan-state-myanmar). Latin American literature also stressed the nature of conflicts as defense of one's territory against the expansion of the "extractivist frontier" and its local cultural impacts [58, 59]. Chinese capital is advancing very fast in a number of megaprojects in Latin America, including energy infrastructures, at least since 2008 [60], often justified as green financing of development and integration of the region [61]. The Cola Codo Sinclair project in Ecuador, Cachuela Esperanza on 
the River Beni in Bolivia [61], and the large scale hydroelectric exploitation of the Patuca River in Honduras [62] are examples of the first Chinese dam-developers' engagement in the region which have resulted in contestations from local groups due to the loss of cultural diversity. Chinese dam construction was also found to exacerbate historical tensions because of its development in culturally fragile zones in Asia [65]. Examples are the development of Myanmar's Salween dams in areas of ethnic conflict, such as the Hatgyi dam in Karen state (EJAtlas Database, URL: https://ejatlas.org/conflict/hatgyi-dam-myanmar), or the Kunlong dam in Shan State (EJAtlas Database, URL: https://ejatlas.org/conflict/kun-long-dam-on-the-salween-river-myanmar ). Concerns were voiced they could trigger reoccurrences of armed conflict and threaten a fragile peace process between ethnic armed groups and the Myanmar Army [63*].

\section{Conclusion}

Chinese large dam builders and financiers dominate the international large hydropower industry in terms of size, speed of investment and global coverage. There is the potential for Chinese large hydropower dam development to provide energy access to poor countries. Still nearly 20 years after the World Commission on Dams' report has been published, which openly condemned the negative implications of large dams on local populations and the environment, environmental justice concerns and conflicts associated with large dams remain unsolved problems in the global South. The way Chinese actors engage with the host governments and local populations, such as the "nostring attached" policy, bundling of aid, trade and investments, limited responsibility and engagement with the local socio-environmental context, and dam-building in ecologically and culturally fragile zones, has raised a vivid debate in academia, in the media, as well as within civil society organizations. While research on the implications of Chinese large hydropower dam development in Asia and Africa is advancing, there is far too little research which looks at environmental justice and other geographical areas, such as for instance Latin America. This paper aims to make a valuable contribution for opening up debates and future research on environmental justice and contested aspects of Chinese and non-Chinese large hydropower expansion in the global South.

\section{Acknowledgements}

This work was supported by the Volkswagen Foundation, the Wellcome Trust, and the Svenska Riksbankens Jubileumsfond by funding the Green Transformations in the Global South (GreeTS) project; the UK Economic and Social Research Council (ESRC) by funding the China's goes global project [grant number ES/J01320X/1]; and the European Research Council for the EnvJustice project at ICTA-UAB [grant number GA 695446]. The authors would like to thank Joan Martinez-Alier and an anonymous reviewer for their highly valuable comments.

\section{References}

[1] Zarfl C, Lumsdon EA, Berlekamp J, Tydecks L, Tockner K:. A global boom in hydropower dam construction. Aqu Sci 2015, 77:161-170 
[2] WCD (Eds): Dams and Development. A New Framework for Decision Making. Report of the World Commission on Dams. Earthscan Publications Ltd, London and Sterling, VA; 2000.

[3**] Del Bene D, Scheidel A, Temper L: More dams, more violence? A global analysis on resistances and repression around conflictive dams through co-produced knowledge. Sustainability Science 2018, 13 (3): 617-633.

In this paper a unique database of 220 dam-related environmental conflicts, retrieved from the Global Atlas on Environmental Justice (EJAtlas), and based on knowledge co-production between academics and activists is analyzed.

[4] Jensen-Cormier S: Reflections on Chinese Companies' Global Investments in the Hydropower Sector between 2006-2017, International Rivers 2017.

[5] China Policy, 2017: China going global. Between ambition and capacity, Beijing, China.

[6**] Tan-Mullins M: Dancing to China's Tune: Understanding the Impacts of a Rising China through the Political-Ecology Framework. Journal of Current Chinese Affairs 2017a, 46 (3): 3-32.

This paper by utilising the political ecology approach evaluates the transnational impacts of a rising China looking at hydropower and the mineral sector.

[7] McDonald K, Bosshard P, Brewer N: Exporting dams: China's hydropower industry goes global. J. Environ. Manag. 2009, 90 (3): 294-302. http://dx.doi.org/10.1016/j.jenvman.2008.07.023.

[8] Hensengerth O: Chinese Hydropower Companies and Environmental Norms in Countries of the Global South: The Involvement of Sinohydro in Ghana's Bui Dam. Environment, Development and Sustainability 2013, 15(2): 285-300. DOI: 10.1007/s10668-012-9410-4

[9] Urban F, Nordensvard J, Siciliano G, Li B: Chinese overseas hydropower dams and social sustainability: The Bui Dam in Ghana and the Kamchay Dam in Cambodia. Asia \& the Pacific Policy Studies 2015, 2(3): 573-589.

[10*] Chan DSW: Asymmetric bargaining between Myanmar and China in the Myitsone Dam controversy: social opposition akin to David's stone against Goliath. Pac. Rev. 2017: 1-18. http://dx.doi.org/10.1080/09512748.2017.1293714.

Drawing on 35 interviews with anti-dam campaigners and other stakeholders in Myanmar, this article shows how bilateral agreement between Chinese investors and local partners without domestic endorsement can result in dam construction failure.

[11*] Urban F, Siciliano G, Nordensvard J: China's Dam Builders: their role in transboundary river management in Southeast Asia, Int. J. Water Resour. Dev. 2018, 34(5): 747-770 http://dx.doi.org/10.1080/07900627.2017.1329138.

This article investigates China's role as large dam builder in the Greater Mekong Sub-Region in South-East Asia. It addresses the environmental, social, economic and political implications of large dams' construction in the area by drawing on case studies from Cambodia and Vietnam. 
[12*] Yankson PWK, Asiedu A, Owusu K, Urban F, Siciliano G: The livelihood challenges of resettled communities of the Bui Dam project in Ghana and the role of Chinese dam-builders, Dev. Policy Rev. 2016, 36: 476-494, http://dx.doi.org/10.1111/dpr.12259.

By conducting 43 interviews and 11 focus group discussions in Ghana this article examines the nature of the livelihood challenges for resettled communities due to the construction of the Bui hydropower project, their causes, and why they were not avoided and the role of the Chinese builders. The paper found that while Chinese dam-builders played a major role in financing and enabling the dam's construction, the Ghanaian governance arrangements were found to be more important in addressing the livelihood challenges.

[13**] Kirchherr J, Matthews N, Charles KJ, Walton MJ: "Learning it the Hard Way": social safeguards norms in Chinese-led dam projects in Myanmar, Laos and Cambodia. Energy Policy 2017, 102: 529-539. http://dx.doi.org/10.1016/j.enpol.2016.12. 058.

This paper analyses social safeguard norms in Chinese-led dam projects in Myanmar, Laos and Cambodia. The paper finds that in recent years Chinese builders increasingly take into account international norms. The authors argue that the root cause for this change is social mobilization against Chinese dam projects.

[14] Matthews N, Motta S: Chinese State-Owned Enterprise Investment in Mekong Hydropower: Political and Economic Drivers and Their Implications across the Water, Energy, Food Nexus. Water 2015, 7: 6269-6284 doi:10.3390/w7116269.

[15**] Tan-Mullins M, Urban F, Mang G: Evaluating the behaviour of Chinese stakeholders engaged in large hydropower projects in Asia and Africa. China Q. 2017b, 230: 464-488 http://dx. doi.org/10.1017/S0305741016001041

This paper explores the interests of Chinese stakeholders and investigates the wider implications of Chinese dams on the local, national and international contexts. The paper concludes that the planning, building and mitigation strategies of Chinese dam-building need to be implemented in a more sustainable way that takes into account national development priorities, the needs of local people and the impacts on natural habitats.

[16**] Siciliano G, Urban F (Eds): Chinese Hydropower Development in Africa and Asia: Challenges and Opportunities for Sustainable Global Dam-Building. Routledge, London Press; 2018.

This book explores the governance and socio-economic implications of large Chinese dams' development in low- and middle-income countries in Asia and Africa and looks at how these big infrastructure projects promote sustainable local and national development in the recipient countries.

[17] Du MM: China's “One Belt, One Road” initiative: context, focus, institutions, and implications. Chin. J. Glob. Gov. 2016, 2: 30-43. http://dx.doi.org/10.1163/23525207- 12340014.

[18*] Motta S, Matthews N: Rewards and Risks of Chinese Hydropower in the Greater Mekong Subregion (GMS). In Chinese Hydropower Development in Africa and Asia: Challenges and Opportunities for Sustainable Global Dam-Building. Edited by Siciliano G, Urban F. Routledge, London Press; 2018: 21 
This chapter explores the incentives, disincentives and risks for Mekong governments and Chinese actors to partner in hydropower development in the Greater Mekong Sub-region- namely, Cambodia, Lao PDR, Myanmar, Thailand, and Viet Nam.

[19] NDRC and NEA: Energy Supply and Consumption Revolution Strategy (2016-2030). 2017, Beijing, China URL: http://www.gov.cn/xinwen/201704/25/5230568/files/286514af354e41578c57ca38d5c4935b.pdf

[20] Urban F, Nordensvärd J, Khatri D, Wang Y: An analysis of China's investment in the hydropower sector in the Greater Mekong Sub-Region. Environ. Dev. Sustain 2013, 15: 301-324. http://dx.doi.org/10.1007/s10668-012-9415-z

[21*] Kirchherr J, Matthews N: Technology transfer in the hydropower industry: An analysis of Chinese dam developers' undertakings in Europe and Latin America. Energy Policy 2018, 113: 546558.

This paper identifies the extent, drivers and inhibitors of technology transfer of Chinese dam developers' undertakings in Europe and Latin America. The paper found relatively few Chinese undertakings and thus limited evidence for technology transfer both in Europe and Latin America. Transfers identified are frequently mutual with the Chinese player transferring technology to the host country and vice versa.

[22] Odoom I: Dam in, Cocoa out; Pipes in, Oil out: China's engagement in Ghana's energy sector. J. Asian Afr. Stud. 2015, 52: 598-620. http://dx.doi.org/10.1177/ 0021909615599419.

[23] Blocksom B, Locatelli P: Chinese dam builder eyeing major Amazon mega-dam contract. WWW Document 2016, Mongabay, 26 February 2016.

[24] Alvaro, M: China, Ecuador Sign \$2 Billion Loan Deal, WWW Document, Wall Str. J. 2011,URL 〈https://www.wsj.com/articles/ SB10001424052702304314404576412373916029508).

[25] Middleton M: The sleeping dragon awake. China's growing role in the business and politics of hydropower development in the Mekong Region, Watershed 2008, 12(3).

[26] McDonald K, Bosshard P, Brewer N: Exporting dams: China's hydropower industry goes global. J. Environ. Manag. 2009, 90(3): 294-302. http://dx.doi.org/ 10.1016/j.jenvman.2008.07.023.

[27] Tseng HK Krog R: No Strings Attached: Chinese Foreign Aid and Regime Stability in ResourceRich Recipient Countries, Department of Political Science George Washington University 2016: URL: file:///C:/Users/gs45/Downloads/NoStringsAttachedChineseForeignAid_preview\%20(1).pdf

[28] Urban F, Nordensvard J, Siciliano G, Li B: Chinese overseas hydropower dams and social sustainability: the Bui dam in Ghana and the Kamchay dam in Cambodia. Asia Pac. Policy Stud. 2015, 2: 573-589. http://dx.doi.org/10.1002/app5.103.

[29] Erlewein A: The Promotion of Dams Through the Clean Development Mechanism: Between Sustainable Climate Protection and Carbon Colonialism. In: Large Dams in Asia. Advances in Asian Human-Environmental Research. Edited by Nüsser M. Springer, Dordrecht Press; 2014: 149-168.

[30] Wehrli B: Climate science: renewable but not carbon-free. Nat Geosci 2011, 4:585-586. 
[31] Fearnside PM: Emissions from tropical hydropower and the IPCC. Environmental Science \& Policy 2015, 50: 225-239.

[32] Erlewein A, Nüsser R: Offsetting Greenhouse Gas Emissions in the Himalaya? Clean Development Dams in Himachal Pradesh, India. Mountain Research and Development 2011, 31(4): 293-304.

[33] Haya B, Parekh P: Hydropower in the CDM: Examining additionally and criteria for sustainability, Energy and Resources Group, Working Paper ERG-11-001 2011: University of California, Berkeley.

[34] Fearnside PM, Pueyo S. Greenhouse-gas emissions from tropical dams. Nature Climate Change 2012, 2(6): 382

[35] Maeck A, Delsontro T, McGinnis DF, Fischer H, Flury S, Schmidt M, Fietzek P, Lorke A: Sediment trapping by dams creates methane emission hot spots, Environ Sci Technol. 2013, 6,47(15): 8130-7. doi: $10.1021 /$ es4003907

[36] Nüsser M, Baghel R: The emergence of technological hydroscapes in the Anthropocene: socio hydrology and development paradigms of large dams. In Handbook on geographies of technology. Edited by Warf B. Edward-Elgar Press; 2017: 287-301.

[37] Sellamuttu SS, Suhardiman D, Lebel L.: Hydropower, Livelihoods, and Benefit Sharing: Innovations in Policies and Programs, Water Resources and Rural Development 2014; 4.

[38] Marques S, Lima MS, Moreira S, Reis J: Local identity as an amplifier: procedural justice, local identity and attitudes towards new dam projects, J. Environ. Psychol. 2015, 41: 63-73.

[39] Martinez V, Castillo OL: The political ecology of hydropower: Social justice and conflict in Colombian hydroelectricity development. Energy Research \& Social Science 2016; 22: 69-78 https://doi.org/10.1016/j.erss.2016.08.023

[40] Hess CEE, Costa Ribeiro W, Wieprecht S: Assessing Environmental Justice in Large Hydropower Projects: The Case of São Luiz do Tapajós in Brazil, Desenvolv. Meio Ambiente 2016, 37: 91-109.

[41] Sayan RC: Urban/rural division in environmental justice frameworks: revealing modernityurbanisation nexus in Turkey's small-scale hydropower development, The International Journal of Justice and Sustainability 2016, 22(12): 1510-1525. doi.org/10.1080/13549839.2017.1368465

[42] Scheidel A, Temper L, Demaria F, Martinez-Alier J: Ecological distribution conflicts as forces for sustainability: an overview and conceptual framework, Sustainability Science 2018, 13(3): 585-598 https://doi.org/10.1007/s11625-017-0519-0

[43] Sovacool BK, Heffron RJ, McCauley D, Goldthau A: Energy decisions reframed as justice and ethical concerns, Nat. Energy 2016, 1: 16-24.

[44**] Siciliano G, Urban f, Tan-Mullins M, Mohan G: Large dams, energy justice and the divergence between international, national and local developmental needs and priorities in the global South, Energy Research and Social Science 2018, 41: 199-209.

This paper proposes a conceptual framework called "The Energy Justice Framework for Dam Decision-Making" as a tool to inform energy decisions on infrastructure development based on energy justice principles and social impact assessment. The framework is used to analyse 
distributional, procedural, restorative justice, and power relations of four Chinese large dams' projects located in Africa and Asia.

[45] Bridge G, Bouzarovski S, Bradshaw M, Eyre N: Geographies of energy transition: Space, place and the low-carbon economy. Energy Policy 2013, 53: 331-340

[46] Sovacool BK, Valentine SV: Bending bamboo: restructuring rural electrification strategy in Sarawak Malaysia. Energy Sustain. Dev. 2011, 15(3): 240-253.

[47*] Majid Cooke F, Saat G, Urban F, Siciliano G: Chinese dam building, renewable energy and socioecological change in East Malaysia. In Chinese Hydropower Development in Africa and Asia: Challenges and Opportunities for Sustainable Global Dam-Building. Edited by Siciliano G, Urban F. Routledge, London Press; 2018, 17.

This chapter addresses wider socio-economic and political drivers of large-dam building in Malaysia and the role of Chinese actors as financiers and dam builders in a context where Malaysian political and economic as well as national and sub-regional elite interests dominate.

[48*] Fam S D: China Came, China Built, China Left?: The Sarawakian Experience with Chinese. Journal of Current Chinese Affaires 2017, 46(3): 49.

The paper looks from a political ecology approach at Chinese and Australian enterprises involved in the Bakun Hydroelectric Dam construction in Sarawak, Malaysia. Results show that dam builders and indigenous communities displayed different understandings with regards to social and environmental safeguards. Indigenous communities were dispossessed from their land, affecting their ability to successfully reconstruct their livelihoods.

[49*] Owusu K, Yankson PWK, Asiedu AB, Obour B: Resource utilization conflict in downstream nonresettled communities of the Bui Dam in Ghana. Nat. Resour. Forum 2017, 41: 233-243.

This study examines the downstream social impacts of the Chinese built Ghana's Bui Dam. It identifies resource use conflicts in the non-resettled communities within a $30 \mathrm{~km}$ stretch along the course of the Black Volta River below the dam.

[50*] Majid Cooke F, Nordensvard J, Bin Saat G, Urban F, Siciliano G: The limits of social protection: the case of hydropower dams and indigenous peoples land. Asia Pac. Policy Stud. 2017, 4(3): 437450, http://dx.doi.org/10.1002/app5.187.

This article analyses the social protection measures designed for the protection of Indigenous peoples and their livelihoods in the case of the Chinese built Bakun dam in Malaysia. The article finds that the building of the dam facilitated a commodification process of both land and people, understood as a colonisation of their land and their cultures.

[51*] Siciliano G, Urban F, Tan-Mullins M, Pichdara L, Kim S: The political ecology of Chinese large dams in Cambodia: implications, challenges and lessons learnt from the Kamchay dam. Water 2016, 82: 405. http://dx.doi.org/10.3390/w8090405.

Using a "Political ecology of the Asian drivers" framework, this paper assesses China's involvement in the development of large dams' in Cambodia and its impacts on the access of natural resources such as water and energy by dam builders, local communities and the government.

[52] Hesengerth O: Water Governance in the Mekong Basin: Scalar Tradeoffs, Transnational Norms and Chinese Hydropower Investment, In: Chinese Encounters in Southeast Asia: How People, 
Money, and Ideas from China Are Changing a Region. Edited by Nyiri P, Tan D. University of Washington Press, Seattle; 2017a: 174-180.

[53] Heffron RJ, McCauley D: The concept of energy justice across the disciplines. Energy Policy 2017, 105: 658-667

[54*] Ying Q, Mang G, Bosshard P: Benchmarking the Environmental and Social Management Policies and Practices of Chinese Overseas Dam Builders, in: In Chinese Hydropower Development in Africa and Asia: Challenges and Opportunities for Sustainable Global Dam-Building. Edited by Siciliano G, Urban F. Routledge, London Press; 2018, 17

This chapter presents and discusses the results of a global benchmarking project carried out by International Rivers which looked at the environmental and social policies and project performance practices of Chinese overseas hydropower companies.

[55*] Pheakdey H: Hydropower and local community: A case study of the Kamchay dam, a Chinafunded hydropower project in Cambodia.Community Development 2017, 48(3): 385-402. DOI: $10.1080 / 15575330.2017 .1304432$.

This article examines the impacts of the China-funded Kamchay hydropower project in Cambodia on the local community two years after it began operating. This article contributes to the ongoing debate on Chinese involvement and the effects of large-scale natural resource investments on sustainable development in Cambodia.

[56*] Urban F: China's rise: Challenging the North-South technology transfer paradigm for climate change mitigation and low carbon energy, Energy policy 2018, 113: 320-330.

This paper shows that for low carbon innovation, there is an increase in indigenous innovation capabilities, resulting in South-South technology transfer and cooperation from China to the South as well as elements of 'reverse' South-North technology cooperation.

[57**] Hensengerth O: Regionalism, Identity, and Hydropower Dams: The Chinese-Built Lower Sesan 2 Dam in Cambodia, Journal of Current Chinese Affairs 2017, 46 3, 85-118.

This paper argues, based on concepts of regional identity and on the literature examining the links between culture and water, that Chinese actors driving the hydropower development in the Greater Mekong Subregion have exacerbated social tensions, thus failing to establish social coherence in the region.

[58] Escobar, A (Eds): Territories of difference: place, movements, life, redes. Duke University Press; 2008

[59] Alimonda H, Toro Pérez C, Martín F (Eds): Ecología Política Latinoamericana. CLACSO Press; 2017 1/2. 2017.

[60] Gallagher KP, Koleski, K, Irwin, A: Las finanzas chinas en Latinoamérica:¿ un financiamiento más verde?. Revista de Ciencias Sociales 2014, 39(71): 33-60.

[61] Osava M: Bolivia: Dam Spells Hope and Fear for Small Jungle Town, Inter Press Service New Agency 2011.

[62] Mowforth M: The Violence of Development: Resource Depletion, Environmental Crises and Human Rights Abuses in Central America. Pluto Press London: 2014. 
[63*] Suhardiman D, Rutherford J, Bright, S J: Putting violent armed conflict in the centre of the Salween hydropower debates. Critical Asian Studies 2017, 49(3): 349-364. https://doi.org/10.1080/14672715.2017.1328284.

This paper shows that in Myanmar hydropower dam projects could contribute to and trigger reoccurrences of violent armed conflict.

[64] Nordensvard, J. and Urban, F., 2015. Social innovation and Chinese overseas hydropower dams: The nexus of national social policy and Corporate Social Responsibility. Sustainable Development, Vol.23(7-8): 245-256.

[65] Faber DR (2005) Building a Transnational Environmental Justice Movement: Obstacles and Opportunities in the Age of Globalization. In: Bandy J, Smith J (eds) Coalitions Across Borders: Transnational Protest and the Neoliberal Order, pp. 43-68. Rowman and Littlefield, Lanham, MD. [66*] Schlosberg D (2007) Defining Environmental Justice. Theories, Movements, and Nature. Oxford University Press, Oxford.

This book explores what, exactly, is meant by 'justice' in definitions of environmental and ecological justice.

[67] Schlosberg D (2013) Theorising Environmental Justice: The Expanding Sphere of a Discourse. Environmental Politics 22(1), 37-55.

[68] Urban, F., Siciliano, G., Wallbott, L., Lederer, M., Anh, D.N., 2018. Green transformations in Vietnam's energy sector. Asia \& the Pacific Policy Studies, https://doi.org/10.1002/app5.251.

[69] Sovacool, B. K., Heffron, R. J., McCauley, D., \& Goldthau, A. (2016). Energy decisions reframed as justice and ethical concerns. Nature Energy, 1, 16024. https://doi.org/10.1038/nenergy.2016.24

[70] Richter, B.D.; Postel, S.; Revenga, C.; Scudder, T.; Lehner, B.; Churchill, A. and Chow, M. 2010. Lost in development's shadow: The downstream human consequences of dams. Water Alternatives $3(2): 14-42$

[71] Abbink, J., 2012. Dam controversies: contested governance and developmental discourse on the Ethiopian Omo River dam. Social Anthropology, https://doi.org/10.1111/j.1469-8676.2012.00196.x

[72] Moran, E.F., Lopez, M.C., Moore, N., Müller, N., Hyndman, D.W., 2018. Sustainable hydropower in the 21st century. PNAS November 20, 2018115 (47) 11891-11898. 